\title{
NUTRITIONAL AND BIOACTIVE COMPOUNDS IN HOT FRUITS OF CAPSICUM ANNUUM L. FROM MACEDONIA
}

\author{
Jana Simonovska $^{1}$, Vesna Rafajlovska ${ }^{1 *}$, Zoran Kavrakovski $^{2}$, Marija Srbinoska $^{3}$ \\ ${ }^{1}$ Faculty of Technology and Metallurgy, Ss. Cyril and Methodius University, Skopje, Republic of Macedonia \\ ${ }^{2}$ Faculty of Pharmacy, Ss. Cyril and Methodius University, Skopje, Republic of Macedonia \\ ${ }^{3}$ Scientific Tobacco Institute, University St. Kliment Ohridski - Bitola, Prilep, Republic of Macedonia \\ e-mail: vesna@tmf.ukim.edu.mk
}

\begin{abstract}
In the pericarp, placenta and seed of red hot pepper fruits (Capsicum annuum L. ssp. microcarpum longum conoides convar. Horgoshka), the quantity of proteins, minerals, cellulose and reductive sugars, as well as the quantity of capsaicinoids and carotenoids was determined.

The protein content in the pericarp, seed and placenta was $14.13 \%, 20.88 \%$, and $25.19 \%$ from the total dry matter (DM) weight, respectively. The pericarp was the richest in cellulose $(26.37 \%$ DM) compared to the cellulose content in the seed $(22.66 \% \mathrm{DM})$ and placenta $(15.05 \% \mathrm{DM})$. The average quantity of potassium and magnesium in the seed was 5209 and $4176 \mathrm{mg} \mathrm{kg}^{-1}$ DM. The largest quantity of colored substances, expressed as the capsanthin content $(0.42 \% \mathrm{DM})$, was found in the pericarp. The capsaicin content in DM weight of the pericarp, seed and placenta was $5.38 \mathrm{mg} \mathrm{g}^{-1}, 2.36 \mathrm{mg} \mathrm{g}^{-1}$ and 10.48 $\mathrm{mg} \mathrm{g}^{-1}$, respectively. The Scoville heat value of 109923 SHU calculated for the pericarp revealed that this pepper variety can be qualified as very pungent. High amounts of total capsaicinoids in the placenta (16.91 $\left.\mathrm{mg} \mathrm{g}^{-1} \mathrm{DM}\right)$ and in the seed $\left(3.51 \mathrm{mg} \mathrm{g}^{-1} \mathrm{DM}\right)$ were found. Although designated as inedible parts of hot red pepper fruits, the placenta and seed are promising sources of valuable nutritional and biological compounds confirmed by the results of this study.
\end{abstract}

Keywords: Capsicum annuum L.; chemical composition; macro- and microelements; capsanthin; capsaicinoids

\section{НУТРИТИВНИ И БИОАКТИВНИ КОМПОНЕНТИ НА ПИПЕРКАТА CAPSICUM ANNUUM L. ОД МАКЕДОНИЈА}

Утврдено е количеството на белковините, минералите, целулозата и редуктивните шеќери, како и на капсаициноидите и каротеноидите во перикарпот, плацентата и семето на црвената лута пиперка (Capsicum annuит L. ssp. microcarpum longum conoides convar. Horgoshka).

Содржината на белковините во перикарпот, семето и плацентата изнесува соодветно $14,13 \%, 20,88 \%$ и 25,19 \% од вкупната маса на сувата материја (CM). Најголемо количество на целулоза содржи перикарпот $(26,37$ \% СM), во споредба со семето $(22,66$ \% СМ) и плацентата $(15,05 \%$ CM). Просечното количество на калиум и магнезиум во семето изнесува 5209 и $4176 \mathrm{mg}$ $\mathrm{kg}^{-1} \mathrm{CM}$. Најголемо количество на обоени супстанции, изразено преку содржината на капсантин $(0,42 \%$ CM), беше утврдено во перикарпот. Содржината на капсаицин, изразена во однос на СM, кај перикарпот, семето и плацентата беше, соодветно, $5,38 \mathrm{mg} \mathrm{g}^{-1}, 2,36 \mathrm{mg} \mathrm{g}^{-1}$ и 10,48 $\mathrm{mg} \mathrm{g}^{-1}$. Пресметаната вредност на индексот за лутина од 109923 SHU по Сковил (Scoville) кај перикарпот покажува дека оваа сорта на пиперка може да се оквалификува како многу лута. Определена е и висока содржина на вкупни капсаициноиди во плацентата $\left(16,91 \mathrm{mg} \mathrm{g}^{-1} \mathrm{CM}\right)$ и во семето $(3,51 \mathrm{mg}$ $\left.\mathrm{g}^{-1} \mathrm{CM}\right)$. Иако се работи за делови на плодот од лутата црвена пиперка кои не се јадат, плацентата и семето се ветувачки извор за добивање вредни хранливи и биолошки компоненти, што е потврдено со резултатите од ова испитување. 
Клучни зборови: Capsicum anпuит L.; хемиски состав; макро- и микроелементи; капсантин; капсаициноиди

\section{INTRODUCTION}

Pepper (Capsicum annuum L., Solanaceae) is recognized as a widely distributed vegetable crop in the world. The sweet and hot pepper varieties are included in the nutrition and food processing industry. They are consumed either fresh or processed, in various specialties or as spices and extracts, namely oleoresins. Pepper is an excellent source of proteins, vitamins, ascorbic acid, minerals, fats and oils, phenolic compounds, aromatic substances and other biologically active compounds [1-6]. Due to the presence of characteristic compounds, capsaicinoids and carotenoids, the red hot pepper varieties and their oleoresins have a significant place in the food and pharmaceutical industry [7-9].

In the group of capsaicinoids, which are identified as the main determinants of the pungency of the pepper, capsaicin is predominant in quantity followed by dihydrocapsaicin, nordihydrocapsaicin, homodihydrocapsaicin and homocapsaicin [10]. Over the years, the number of pharmacological actions of capsaicin has increased, but in the last twenty years, particular attention has been dedicated to the determination and confirmation of its specific activities. Many studies have considered the action of capsaicin as a pain reliever. The activity of capsaicin in anticancer therapy has been confirmed not only in vitro, but also in vivo studies [11, 12]. Also, the impact of capsaicin in reducing body fat through the process of thermogenesis, and thus in the regulation of body weight, has been studied $[13,14]$. Capsaicin plays a significant role in maintaining the cardiovascular and gastrointestinal system [15], while as a pharmacological agent in urology, it is used for reducing the glucose level in blood [16]. It is also suitable for haematuria treatment [17]. Moreover, the capsaicinoids are designated as natural product-based food additives, as antimicrobial agents [18-20], and even as selfdefense product constituents [21]. The positive effect of capsaicin has also been confirmed by the deposition of carotenoids in egg yolk color, as well as in the stimulation of the egg production process in chickens [22, 23]. Capsanthin and capsorubin are the main carotenoids responsible for the deep red color of the pepper. Besides their main role as a colorant, they are also recognized as antioxidants and inhibitors of colon cancer cells [3, 24].
The content of nutritional and biological active compounds in the fruits of hot red peppers may vary considerably depending on numerous factors, i.e. fruit structural characters, degree of ripeness, environmental conditions, time of vegetation, soil conditions, genetic factors as well as the country of origin [25-28].

The lack of numerous literature data related to the content of nutritional and biologically active compounds in the fruits of hot varieties of Capsicum in the Republic of Macedonia contributed to define the aim of this study, with a focus on determining the quantity of these compounds in the constitutional parts of fruits of hot red pepper, i.e. in the pericarp, seed and placenta.

\section{EXPERIMENTAL}

\subsection{Materials}

\subsubsection{Plant material}

Pepper, Capsicum annuum L., was grown in the locality of Markova Češma, Prilep (geographical location: +41'21'36" N latitude, +21³3'36" E longitude and $640 \mathrm{~m}$ altitude), Republic of Macedonia, in the year 2012. The basic treatment of the soil was performed by deep ploughing up to 40-50 $\mathrm{cm}$. In order to make it soft prior to sowing, the soil was ploughed by turning over. Prior to the autumn ploughing and planting out of the seedlings, 20-30 $\mathrm{tha}^{-1}$ manure and $2 \mathrm{tha}^{-1}$ macronutrients, i.e. nitrogen, phosphorus and potassium (NPK), 10:30:20, respectively, were added. The nitrogen fertilizer was added three times, first with $300 \mathrm{~kg}$ $\mathrm{ha}^{-1}$ calcium ammonium nitrate (CAN) 25-30 days after planting, the second time 20-25 days after the first addition, and the third time in the stage of intensive growth of fruits, in combination CAN (27\% calcium ammonium nitrate) and NPK (10:30:20), $200 \mathrm{~kg} \mathrm{ha}^{-1}$ each. The average monthly air temperature ranged between $11.7^{\circ} \mathrm{C}$ and 19.1 ${ }^{\circ} \mathrm{C}$ during the vegetation of the pepper from May to September 2012. The total amount of precipitation in the period of vegetation was $180 \mathrm{~mm} \mathrm{~m}^{-2}$. Irrigation was applied by a drip irrigation system (300 $\mathrm{m}^{3}$ water $\mathrm{ha}^{-1}$ ) from the hydrosystem in Prilep. The seed of this pepper variety was from the manufacturer's own production. For many years, this variety pepper has been grown in the area Markova Češma and has been adapted to outdoor growing 
conditions. The vegetation period of the variety pepper was 70 days. The fruits are usually harvested when they are full grown and mature, 10.5 to $11.5 \mathrm{~cm}$ long, firm and deep red. They were harvested manually, and dried in a dry and ventilated place. After drying, they were cut manually longitudinally with a knife, and pericarp was separated from the seed and placenta of the dry fruits and ground using a Retsch ZM1 mill (Germany), with a $0.5 \mathrm{~mm}$ sieve. The pepper samples were placed in dark glass bottles and stored at $4{ }^{\circ} \mathrm{C}$ in a refrigerator. The determination of the pepper variety was done at the Faculty of Agricultural Sciences and Food, at Ss. Cyril and Methodius University in Skopje, R. Macedonia. The pepper belongs to the species Capsicum annuum L., ssp. microcarpum longum conoides, convar. Horgoshka. The fruit size characteristics were determined by measuring the length from the base to the apex of the fruit without the pedicle and the width at the widest part of the fruit. The weight fraction of the pericarp, placenta, seed and stem was determined by weighing the fruit part with $0.0001 \mathrm{~g}$ accuracy. The length and weight, as well as the weight fraction of the separated pericarp, seed, placenta and stem of the fruit were determined as an average value of ten measurements. In general, the fruits of this dry red hot pepper were oblong in form, with a typical deep red color, average length of $10.80 \pm 0.72 \mathrm{~cm}$ and average width of $3.26 \pm 0.23 \mathrm{~cm}$. The average weight per separated pericarp, seed, placenta and stem from the dried fruits of red hot pepper was $4.43 \pm 0.02 \mathrm{~g}, 2.37 \pm 0.08 \mathrm{~g}, 1.57 \pm 0.21 \mathrm{~g}$ and 0.49 $\pm 0.14 \mathrm{~g}$, respectively.

\subsubsection{Chemicals}

Reagent grade chemicals used for plant material characterization according to the procedures given in AOAC [29] were supplied from Alkaloid $\mathrm{AD}$ (R. Macedonia) and Merck (Germany). For the extraction of plant materials, reagent grade ethanol (Merck, Germany) was used. The determination of carotenoids and capsaicinoids was done with analytical grade acetone and methanol supplied from Merck (Germany). The capsaicin standard (65\% pure) was supplied by Fluka (Switzerland) and the dihydrocapsaicin standard (90\% pure) was from Sigma-Aldrich Inc. (USA).

\subsection{Extraction of plant material}

The samples of $0.5 \mathrm{~g}$ plant material, weighted to $0.0001 \mathrm{~g}$ accuracy, were extracted with ethanol using a maceration technique in a thermostatic water bath at temperature of $40{ }^{\circ} \mathrm{C}, 180$ min time of extraction and a solid/liquid ratio of 1:25 w/v. After filtration through a fine porosity fritted glass Buchner funnel, the liquid extract was separated from the solids, transferred to a $25 \mathrm{ml}$ volumetric flask and diluted to the calibration mark with ethanol. The extracts were stored in dark glass vials for the analysis of carotenoids and capsaicinoids. The extraction procedure was performed in triplicate.

\subsection{Characterization of plant material}

\subsubsection{Plant material analysis}

For analysis of the chemical constituents of the plant material, the standard analytical methods prescribed by the AOAC were used [29]. The AOAC procedure 925.10 for DM content determination involved drying at $105^{\circ} \mathrm{C}$ until constant mass achievement [29]. The content of ash and sand was determined by burning at $900{ }^{\circ} \mathrm{C}$ until a constant mass was achieved according the procedures 923.03 and 971.3 given by the AOAC [29]. From the nitrogen content $(\mathrm{N})$ determined using the Kjeldahl method according to AOAC procedure 978.04 [29], the protein content was calculated as $\mathrm{N} \times 6.25$. The crude fiber content was determined according to gravimetric procedure 985.29 of the AOAC [29]. Total and reductive sugars were determined using the Bertrand method [30]. The content of macro- and microelements was determined using AOAC procedure 985.29 [29].

\subsubsection{Determination of carotenoids}

The plant material extract $(0.5 \mathrm{ml})$ was dissolved in $10 \mathrm{ml}$ of acetone for the determination of the carotenoid content. The absorbance was measured at wavelength of $460 \mathrm{~nm}$ on a Varian Cary Scan 50 spectrophotometer (Switzerland) in $1 \mathrm{~cm}$ quartz cells, at $25^{\circ} \mathrm{C}$. The carotenoid content was calculated using the extinction coefficient in acetone of the major carotenoid capsanthin $\left({ }^{1 \%} E_{460 \mathrm{~nm}}=\right.$ 2300) in the red pepper [31].

\subsubsection{Determination of capsaicinoids}

A Perkin Elmer Clarus 500 GC gas chromatograph (USA) equipped with a flame ionization detector (FID) and Elite 1 capillary column (30 m $\times 0.53 \mathrm{~mm}$ i.d., $1 \mu \mathrm{m}$ film thickness, Perkin Elmer, USA) was used for capsaicinoid analysis. $1 \mu \mathrm{l}$ of plant material extract was injected at $260{ }^{\circ} \mathrm{C}$. The oven temperature program was as follows: $225^{\circ} \mathrm{C}$ 
at the start, $25^{\circ} \mathrm{C} \min ^{-1}$ to $275^{\circ} \mathrm{C}(1.5 \mathrm{~min}$ hold $)$, $10^{\circ} \mathrm{C} \min ^{-1}$ to $325^{\circ} \mathrm{C}$. Nitrogen carrier gas was applied. The quantity of capsaicin and dihydrocapsaicin were determined from the calibration curves of capsaicin and dihydrocapsaicin. The capsaicinoid content in the plant materials expressed in $\mathrm{mg}$ $\mathrm{g}^{-1}$ dry matter weight was estimated as the sum of capsaicin and dihydrocapsaicin. Scoville heat val- ues (SHU) were calculated from the capsaicinoid content given in mg per kg sample DM by multiplying by a factor of 16.1 [32]. Fig. 1 ( $a, b$ and $c$ ) shows the gas chromatograms of the extract from the pericarp, seed and placenta of red hot pepper, respectively. The first, highest peak shows capsai$\operatorname{cin}\left(1, t_{\mathrm{R}}=5.80 \mathrm{~min}\right)$ followed by the peak of dihydrocapsaicin $\left(2, t_{\mathrm{R}}=5.95 \mathrm{~min}\right)$. (a)

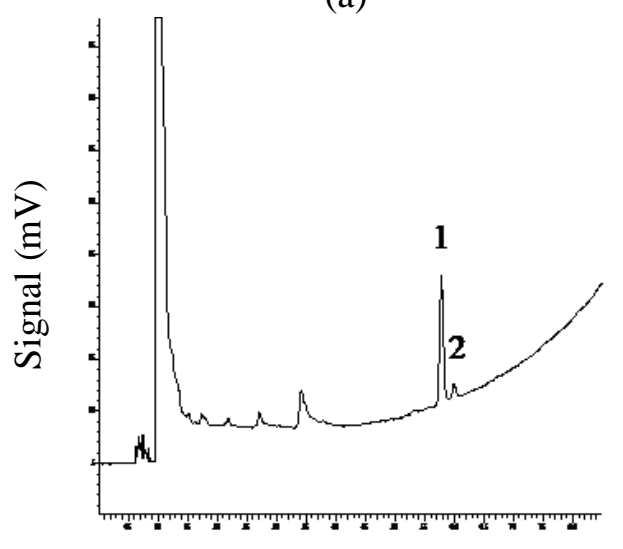

(b)

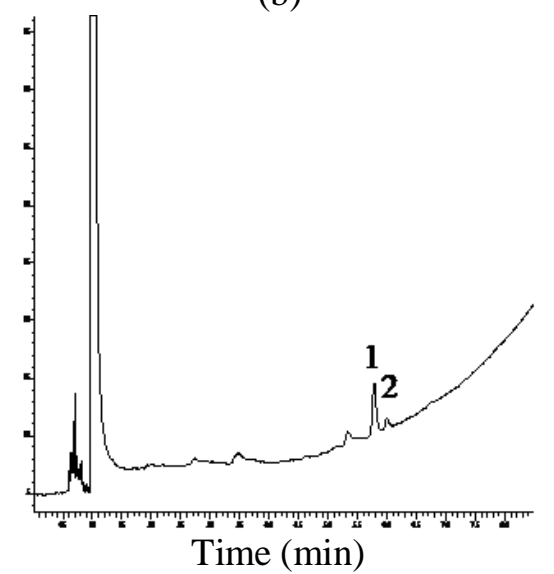

(c)

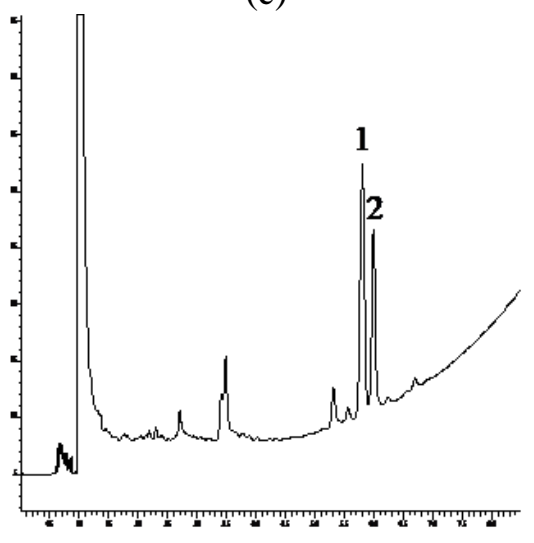

Fig. 1. Gas chromatograms of the extract of the (a) pericarp, (b) seed and (c) placenta of red hot pepper ( 1 - capsaicin; 2 - dihydrocapsaicin)

\subsection{Statistical analysis}

STATISTICA 8 software (StatSoft, Inc., USA) was used in the statistical analysis of the obtained results. The data were analyzed with oneway ANOVA followed by multiple comparisons with Tukey's honest significant difference (HSD) test at the 5\% significance level $(p<0.05)$.

\section{RESULTS AND DISCUSSION}

\subsection{Hot red pepper fruit composition}

The chemical characteristics of the separated pericarp, seed and placenta from the dried fruits of red hot pepper are presented in Table 1. The content of proteins expressed in relation to the corresponding DM was higher in placenta $(25.19 \%)$. The determined cellulose content in the pericarp and seed was $26.37 \%$ and $22.66 \%$, respectively. The content of reductive sugars in the pericarp and placenta was almost six times higher than in the seed, where $2.96 \%$ of the reductive sugars were found. Zacharian and Gobinath [3] reported a protein content of $14-16 \%, \sim 8 \%$ ash, $0.1 \%$ calcium and $0.90 \%$ iron in the pericarp of hot Capsicum.

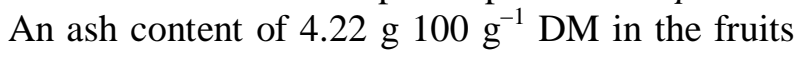
of hot pepper was determined by Ozgur et al. [33]. The literature data for the chemical composition of dried red hot peppers show the following contents: protein $109 \mathrm{~g} \mathrm{~kg}^{-1}$, carbohydrate $462 \mathrm{~g} \mathrm{~kg}^{-1}$, calcium $1230 \mathrm{mg} \mathrm{kg}^{-1}$, phosphorus $1400 \mathrm{~g} \mathrm{~kg}^{-1}$ and iron $1000 \mathrm{~g} \mathrm{~kg}^{-1}$ [34].

\subsection{Content of carotenoids in hot red pepper fruits}

In the pericarp and placenta of dried red hot pepper, the content of carotenoids was 0.42 and $0.37 \%$ DM, respectively (Table 1 ). In mature pepper fruits, the total carotenoid contents in the range between 0.69 to $13.85 \mathrm{mg} \mathrm{g}^{-1} \mathrm{DM}$ were determined by Troconis-Torres et al. [35]. The Habanero chili has a lower content of carotenoids, $14 \mathrm{mg} \mathrm{g}^{-1} \mathrm{DM}$, than Chiltepin chili fruits, $36 \mathrm{mg} \mathrm{g}^{-1} \mathrm{DM}$ [36]. Ozgur et al. [33] published a higher capsanthin content in sweet red pepper (2282.45 mg capsanthin $\mathrm{kg}^{-1}$ ) in comparison to the capsanthin value of $996.38 \mathrm{mg} \mathrm{kg}^{-1}$ determined in a hot variety of Capsicum annuum L. from Lee et al. [37]. The capsanthin quantity in hot peppers varies from 17.55 to $109.5 \mathrm{mg} \mathrm{kg}^{-1}$ [38]. 
T a b le 1

Chemical composition in different parts of red hot pepper

\begin{tabular}{lrrr}
\hline \hline \multirow{2}{*}{ Characteristic } & \multicolumn{3}{c}{ Sample } \\
\cline { 2 - 4 } & \multicolumn{1}{c}{ Pericarp } & \multicolumn{1}{c}{ Seed } & \multicolumn{1}{c}{ Placenta } \\
\hline Dry matter (\%) & $95.60^{a} \pm 0.82$ & $95.50^{a} \pm 0.94$ & $94.50^{a} \pm 0.72$ \\
Proteins (\%) & $14.13^{a} \pm 0.36$ & $20.88^{b} \pm 0.75$ & $25.19^{c} \pm 0.35$ \\
Ash (\%) ${ }^{* 1}$ & $16.32^{a} \pm 0.29$ & $3.76^{b} \pm 0.41$ & $17.99^{c} \pm 0.50$ \\
Sand (\%) ${ }^{* 1}$ & $0.52^{a} \pm 0.03$ & $2.61^{b} \pm 0.19$ & $0.40^{a} \pm 0.05$ \\
Cellulose (\%) & $26.37^{a} \pm 0.57$ & $22.66^{b} \pm 0.69$ & $15.05^{c} \pm 0.46$ \\
Reductive sugars $(\%)^{* 1}$ & $19.73^{a} \pm 0.82$ & $2.96^{b} \pm 0.38$ & $20.42^{a} \pm 0.73$ \\
Carotenoids (\%) $^{* 1}$ & $0.42^{a} \pm 0.04$ & N.D. & $0.37^{a} \pm 0.05$ \\
\hline \hline
\end{tabular}

*Calculated according to the corresponding dry matter (DM).

${ }^{1}$ Data are expressed as mean \pm standard deviation $(n=3)$.

${ }^{a, b, c}$ Values with different superscripts within a row are significantly different (Tukey test, $p<0.05$ ). N.D. - not detected.

\subsection{Macro- and microelement content in hot pepper fruits}

Table 2 presents the summarized content of macro- and microelements determined in different parts of the analyzed red hot pepper fruits. The determined quantity of potassium in the pericarp and placenta was around $5230 \mathrm{mg} \mathrm{kg}^{-1} \mathrm{DM}$. In terms of the contents of $\mathrm{Cu}, \mathrm{Zn}, \mathrm{Mn}$ and $\mathrm{P}$, the highest amounts were found in the seed. In comparison to the pericarp and seed, the placenta was characterized by the highest quantities of $\mathrm{Fe}$ (916.72 $\left.\mathrm{mg} \mathrm{kg}^{-1} \mathrm{DM}\right), \mathrm{Mg}$ and $\mathrm{Ca}$ (4572.95 and $1767.87 \mathrm{mg} \mathrm{kg}^{-1} \mathrm{DM}$, respectively).

Table 2

Macro- and microelements $\left(\mathrm{mg} \mathrm{kg}^{-1} \mathrm{DM}\right)^{* 1}$ in different parts of red hot pepper

\begin{tabular}{lrrr}
\hline \hline \multirow{2}{*}{ Element } & \multicolumn{3}{c}{ Sample } \\
\cline { 2 - 4 } & \multicolumn{1}{c}{ Pericarp } & \multicolumn{1}{c}{ Seed } & \multicolumn{1}{c}{ Placenta } \\
\hline $\mathrm{K}$ & $5232.13^{a} \pm 2.55$ & $5209.93^{b} \pm 2.77$ & $5230.50^{a} \pm 2.08$ \\
$\mathrm{Cu}$ & $13.42^{a} \pm 0.53$ & $20.68^{b} \pm 0.77$ & $19.22^{b} \pm 0.62$ \\
$\mathrm{Zn}$ & $46.42^{a} \pm 1.00$ & $70.32^{b} \pm 0.89$ & $61.73^{c} \pm 1.08$ \\
$\mathrm{Mn}$ & $7.94^{a} \pm 0.73$ & $38.91^{b} \pm 1.03$ & $15.16^{c} \pm 0.66$ \\
$\mathrm{Fe}$ & $446.24^{a} \pm 1.56$ & $195.86^{b} \pm 2.03$ & $916.72^{c} \pm 1.60$ \\
$\mathrm{Mg}$ & $3309.61^{a} \pm 2.67$ & $4176.67^{b} \pm 2.57$ & $4572.95^{c} \pm 2.59$ \\
$\mathrm{Ca}$ & $944.51^{a} \pm 1.92$ & $483.13^{b} \pm 1.17$ & $1767.87^{c} \pm 2.06$ \\
$\mathrm{P}$ & $3.15^{a} \pm 0.08$ & $3.21^{a} \pm 0.10$ & $2.60^{a} \pm 0.70$ \\
\hline \hline
\end{tabular}

*Calculated according to the corresponding dry matter (DM).

${ }^{1}$ Data are expressed as mean \pm standard deviation $(n=3)$.

$a, b, c$ Values with different superscripts within a row are significantly different (Tukey test, $p<0.05$ ).

\subsection{Content of capsaicinoids in hot red pepper fruits}

The capsaicinoid contents determined in the pericarp, seed and placenta differed significantly (Table 3). The highest content of capsaicin was found in the placenta, as well as dihydrocapsaicin, 10.48 and $6.43 \mathrm{mg} \mathrm{g}^{-1} \mathrm{DM}$, respectively. The highest ratio of 3.71 estimated from the quantity of capsaicin and dihydrocapsaicin was calculated in the pericarp. The determined pungency level in placenta of 272211 SHU was almost five times and two times higher than the pungency level in the seed and pericarp, respectively.
As reported in the literature, the content of capsaicinoids is affected by the variety of the hot pepper, as well as by environmental conditions and maturity. Variations in the total capsaicinoid content have been reported by many authors in relation to the influence on the hot red pepper variety. The capsaicin content in ripe fruits of Indian hot pepper cultivars varies from 37.6 to $497.0 \mathrm{mg}$ in $100 \mathrm{~g}$, with the corresponding level of pungency from 15 000 to $300000 \mathrm{SHU}$ [39]. The quantity of total capsaicinoids was $40.07 \mathrm{mg}$ in $100 \mathrm{~g}$ with 750000 SHU in red hot peppers as determined by Lee $e t$ al. [37]. In the fruits of Capsicum varieties cultivated in India, Sanatombi and Sharma [25] established 
T a b le 3

Content of capsaicinoids in different parts of red hot pepper

\begin{tabular}{llcccc}
\hline \hline Sample & $\begin{array}{c}\text { Capsaicin } \\
\left(\mathrm{mg} \mathrm{g}^{-1}\right)^{* 1}\end{array}$ & $\begin{array}{c}\text { Dihydrocapsaicin } \\
\left(\mathrm{mg} \mathrm{g}^{-1}\right)^{* 1}\end{array}$ & $\begin{array}{c}\text { Capsaicin and } \\
\text { dihydrocapsaicin } \\
\text { ratio }\end{array}$ & $\begin{array}{c}\text { Quantity of total } \\
\text { capsaicinoids } \\
(\%)\end{array}$ & $\begin{array}{c}\text { Scoville heat } \\
\text { values } \\
(\text { SHU) }\end{array}$ \\
\hline Pericarp & $5.38^{a} \pm 0.44$ & $1.45^{a} \pm 0.20$ & $3.71^{a}$ & $25.06^{a}$ & $109923^{a}$ \\
Seed & $2.36^{b} \pm 0.06$ & $1.15^{a} \pm 0.01$ & $2.05^{b}$ & $12.87^{b}$ & $56431^{b}$ \\
Placenta & $10.48^{c} \pm 0.22$ & $6.43^{b} \pm 0.15$ & $1.63^{c}$ & $62.07^{c}$ & $272211^{c}$ \\
\hline \hline
\end{tabular}

*Calculated according to the corresponding dry matter (DM).

${ }^{1}$ Data are expressed as mean \pm standard deviation $(n=3)$.

$a, b, c$ Values with different superscripts within a row are significantly different (Tukey test, $p<0.05$ ).

the amount of capsaicin from 0.14 to $0.17 \%$ in Capsicum annuum, 0.65-0.88\% in Capsicum frutescens and 0.79-2.06\% in Capsicum chinense.

According to the high content of capsaicinoids found, Capsicum chinense was classified in a high pungency level group [40, 41]. Higher concentration of capsaicin $(9.177 \pm 0.268$ $\mathrm{mg} \mathrm{g}^{-1}$ ) and pungency level (146 823 SHU) was established in "Nsukka" Capsicum chinense yellow pepper compared to "Zaria tatashe" Capsicum annuиm [42]. In the fresh fruits of the scotch bonnet variety of hot pepper, Gahungu et al. [43] found capsaicin and dihydrocapsaicin quantities of 47.63 $\mathrm{mg} \mathrm{g}^{-1}$ and $23.10 \mathrm{mg} \mathrm{g}^{-1}$, respectively. The total capsaicinoid content ranged from $525.7 \mu \mathrm{g} \mathrm{g}^{-1} \mathrm{DM}$ for Chipotle to $3330.9 \mu \mathrm{g} \mathrm{g}^{-1} \mathrm{DM}$ for Serrano hot pepper [8]. López et al. [44] found that Capsicum chacoense Hunz. contains a higher amount of capsaicin (13.9 mg in $100 \mathrm{~g} \mathrm{DM})$ than Capsicum baccatum L. (12.6 mg in $100 \mathrm{~g} \mathrm{DM}$ ) and Capsicum anпиит L. (10.1 mg in $100 \mathrm{~g} \mathrm{DM})$. The total contents of the capsaicinoids were found in the range between 1758.2 and $7068.9 \mu \mathrm{g} \mathrm{g}^{-1} \mathrm{DM}$, which corresponds to Scoville heat values in the range between 26400 and 106000 SHU [45]. In mature fresh pepper, Perucka and Materska determined that the capsaicin and dihydrocapsaicin contents ranged between 0.28 and $0.59 \mathrm{mg} \mathrm{g}^{-1} \mathrm{DM}$ and 0.12 and $0.34 \mathrm{mg} \mathrm{g}^{-1} \mathrm{DM}$, respectively [46]. Moreover, Kraikruan et al. [47] informed that capsaicin and dihydrocapsaicin contents were the highest in the first harvest in all cultivars and then they decreased in the subsequent harvests. The highest capsaicin content in fruits was found in cultivars grown at a high temperature and in nutrient-rich soils [28, 48]. Johnson and Decoteau [49] suggested that the levels of capsaicin and dihydrocapsaicin increase proportionally as the amount of nitrogen fertilizers increases. The highest content of capsaicin (227 $\mathrm{mg} 100 \mathrm{~g}^{-1}$ of fresh weight) in placenta was found in the "Takanotsume" cultivar [50]. According to the distribution of capsaicinoids in different parts of the fruits, Canto-Flick et al. [51] determined the total capsaicinoid content in the whole fruit, placenta, and pericarp of 18 accessions of Habanero pepper. The placenta of Tunisian red hot pepper varieties has the highest content of capsaicinoids ( 2.32 to $0.065 \mathrm{mg} \mathrm{g}^{-1} \mathrm{DM}$ ) compared to the content of the pericarp and seed, where the determined quantity of capsaicinoids was very low, approximately $0.05 \%$ in pericarp and $0.01 \%$ in seed [27]. According to the total content of capsaicinoids and determined Scoville heat values, the following classification of peppers was proposed [52, 53]: sweet non-pungent varieties $(0.1$ to $0.2 \%, 0-5000$ SHU), moderately pungent $(0.2-0.4 \%, 5000-20000$ SHU), pungent (0.4 to $0.6 \%, 20000-70000 \mathrm{SHU}$ ) and very pungent (to $1.4 \%, 70000-300000 \mathrm{SHU}$ ).

\section{CONCLUSIONS}

The results show that the fruits of hot pepper variety Capsicum annum L., ssp. microcarpum longum conoides, convar. Horgoshka, cultivated in the Republic of Macedonia are characterized by high quantities of nutritional and bioactive constituents. The pericarp, as the edible part of fruit, is a good source of carotenoids, dietary fiber and reductive sugars. The seed and placenta are characterized by a valuable content of proteins and micro- and macroelements. In the placenta, in comparison to the pericarp and seed, over $60 \%$ of the total quantity of capsaicinoids, capsaicin and dihydrocapsaicin was found. The highest quantitative ratio of capsaicin and dihydrocapsaicin was found in the pericarp. The high quantities of capsacinoids determined in the placenta and seed of pepper fruits emphasizes the possibility of exploiting these parts as a raw material in the production of valuable nutraceuticals and pharmaceuticals, despite their previous characterization as waste. The findings ac- 
quired from this research will be valuable when choosing pepper variety for cultivation in the Republic of Macedonia, as well as in the determination of the genotypic and phenotypic variations of pepper from our country and from the different regions in the world.

Acknowledgments. This work was financially supported by the Ministry of Education and Science of the Republic of Macedonia, through Project 05-3234. BIONIKA Pharmaceuticals in Skopje, R. Macedonia is acknowledged for the instrumental analysis support.

\section{REFERENCES}

[1] V. S. Govindarajan, M. N. Sathyanarayana, Capsicum: Production, technology, chemistry and quality; Part V. Impact on physiology, nutrition \& metabolism, structure, pungency, pain and desensitisation sequences, $C R C$ Cri. Rev. Food Sci. Nutr., 29, 435-474 (1991).

[2] J. S. Pruthi, Chemistry and Quality Control of Capsicum and Capsicum products, in: Capsicum, genus Capsicum, A. K. De (Eds), Taylor and Francis, London and New York, 2003, pp. 25-70.

[3] T. J. Zachariah, P. Gobinath, Paprika and Chili, in: Chemistry of Spices, V. A. Parthasarathy, B. Chempakam, T. J. Zachariah (Eds), CAB International, Wallingford, UK, 2008, pp. 260-286.

[4] O. Aniel Kumar, S. Subba Tata, Ascorbic acid contents in chili peppers (Capsicum L.), Not. Sci. Biol., 1, 50-52 (2009).

[5] O. Aniel Kumar, R. S. Appa, S. Subba Tata, Phenolic quantification in some genotypes of Capsicum annиum L., J. Phytol., 2, 87-90 (2010).

[6] S. S. Pawar, N. V. Bharude, S. S. Sonone, R. S. Deshmukh, A. K. Raut, A. R. Umarkar, Chillies as food, spice and medicine: a perspective, Int. J. Pharm. Bio. Sci., 1, 311-318 (2011).

[7] S. De Marino, M. Iorizzi, F. Zollo, Antioxidant activity and biological properties of phytochemicals in vegetables and spices (Capsicum, Laurus, Foeni-culum), Elec. J. Env. Agricul. Food Chem., 7, 3174-3177 (2008).

[8] E. Alvarez-Parrilla, A. L. De La Rosa, R. Amarowicz, F. Shahidi, Antioxidant activity of fresh and processed jalapeño and serrano peppers, J. Agric. Food Chem., 59, 163-173 (2011).

[9] I. Guzman, P. W. Bosland, M. A. O'Connell, Heat, Color, and Flavor Compounds in Capsicum Fruit, in: The Biological Activity of Phytochemicals, Recent Advances in Phytochemistry 41, D. R. Gang (Eds), Springer Science+Business Media, Springer: New York, Dordrecht, Heidelberg, London, 2011, pp. 109-126.

[10] C. B Davis, C. E. Markey, M. A. Busch, K. W. Busch, Determination of capsaicinoids in habanero peppers by chemometric analysis of UV spectral data, J. Agric. Food Chem., 55, 5925-5933 (2007).

[11] H. Knotkova, M. Pappagallo, A. Szallasi, Capsaicin (TRPV1 agonist) therapy for pain relief: farewell or revival, Clin. J. Pain, 24, 143-154 (2008).
[12] M. de Lourdes Reyes-Escogido, E. G. GonzalezMondrago, G. Vazquez-Tzompantzi, Chemical and pharmacological aspects of capsaicin, Molecules, 16, 1253-1270 (2011).

[13] M. P. G. M. Lejeune, E. M. R. Kovacs, M. S. Westerterp-Plantenga, Effect of capsaicin on substrate oxidation and weight maintenance after modest body-weight loss in human subjects, Br. J. Nutr. 90, 651-659 (2003).

[14] H. C. Reinbach, A. Smeets, T. Martinussen, P. Moller, S. Westerterp-Plantenga, Effects of capsaicin, green tea and $\mathrm{CH}-19$ sweet pepper on appetite and energy intake in humans in negative and positive energy balance, Clin. Nutr., 28, 260-265 (2009).

[15] P. Wang, D. Liu, Z. Zhu, Transient receptor potential vanilloid type-1 channel in cardiometabolic protection, J. Korean Soc. Hyperten., 17, 37-47 (2011).

[16] K. Chaiyasit, W. Khovidhunkit, S. Wittayalertpanya, Pharmacokinetic and the effect of capsaicin in Capsicum frutescens on decreasing plasma glucose level, J. Med. Assoc. Thai., 92, 108-113 (2009).

[17] C. C. Uzoh, V. Kumar, A. G. Timoney, The use of capsaicin in loin pain-haematuria syndrome, BJU Int., 103, 236-239 (2008).

[18] S. Kurita, E. Kitagawa, C. Kim, Y. Momose, H. Iwahashi, Studies on the antimicrobial mechanism of capsaicin using yeast DNA microarray, Biosci. Biotechnol. Biochem., 66, 532-536 (2002).

[19] F. B Xing, G. X. Cheng, K. K. Yi, Study on the antimicrobial activities of the capsaicin microcapsules, J. Appl. Polym. Sci., 102, 1318-1321 (2006).

[20] T. Singh, C. Chittenden, In-vitro antifungal activity of chilli extracts in combination with Lactobacillus casei against common sapstain fungi, Int. Biodeter. Biodegr., 62, 364-367 (2008).

[21] E. J. Mendelson, K. B. Tolliver, L. K. Delucchi, J. B. Matthew, C. K. F. Wilson-Harris, P. G. Galloway, P. Berger, Capsaicin, an active ingredient in pepper sprays, increases the lethality of cocaine, Forensic Toxicol., 28, 33-37 (2010).

[22] M. González, E. Castaño, E. Avila, E. González de Mejía, Effect of capsaicin from red pepper (Capsicum sp.) on the deposition of carotenoids in egg yolk, J. Sci. Food Agr., 79, 1904-1908 (1999).

[23] A. Özer, H. Erdost, B. Zik, Histological investigations on the effects of feeding a diet containing red hot pepper on the reproductive organs of the chicken, Phytother. Res., 19, 501-505 (2005).

[24] J. Jaswir, D. Noviendri, R. F Hasrini, F. Octavianti, Carotenoids: Sources, medicinal properties and their application in food and nutraceutical industry, J. Med. Plants Res., 5, 7119-7131 (2011).

[25] K. Sanatombi, G. J. Sharma, Capsaicin content and pungency of different Capsicum spp. cultivars, Not. Bot. Horti Agrobo., 36, 88-90 (2008).

[26] L. Nowaczyk, Technological characteristics of fruit as an average of 25 soft-flesh Capsicum spp. Genotypes, Herba Polon., 57, 38-44 (2011).

[27] S. B. Mansour-Gueddes, N. Tarchoun, S. I. MaaouiaHouimli, S. Saguem, Capsaicinoids content in four Tu- 
nisian hot pepper varieties grown in an open field (Capsicum annuum L.), Continental J. Agronomy, 6, 8 13 (2012).

[28] M. J. Rahman, H. Inden, Effect of nutrient solution and temperature on capsaicin content and yield contributing characteristics in six sweet pepper (Capsicum annuum L.) cultivars, J. Food, Agri. Environ., 10, 524-529 (2012).

[29] AOAC. Official methods of analysis. $16^{\text {th }}$ Eds. Association of Official Analytical Chemists, Inc. Washington, USA, 1995, pp. 780.

[30] J. Trajković, J. Baras, M. Mirić, S. Šiler, Analize životnih namirinica, Tehnološko-metalurški fakultet, Beograd, Serbia, 1983, pp. 168-169.

[31] D. Hornero-Méndez, R. Gómez-Ladrón de Guevara, M. I. Ménguez-Mosquera, Carotenoid biosynthesis changes in five red pepper (Capsicum annuum L.) cultivars during ripening, Cultivar selection for breeding, $J$. $A g$ ric. Food Chem., 48, 3857-3864 (2000).

[32] P. H. Todd, M. G. Bensinger, T. Biftu, Determination of pungency due to capsicum by gas-liquid chromatography, J. Food Sci., 42, 660-665 (1977).

[33] M. Ozgur, T. Ozcan, A. Akpinar-Bayizit, L. YilmazErsan, Functional compounds and antioxidant properties of dried green and red peppers, Afr. J. Agric. Res., 6, 5638-5644 (2011).

[34] Y. Ku, S. Choi, The composition of foods. The Scientific Technology of Kimchi, Korean Institute of Food Development (Eds), Seoul, Korea, 1990, pp. 33-34.

[35] I. G. Troconis-Torres, M. Rojas-López, C. HernándezRodríguez, L. Villa-Tanaca, I. E. Maldonado-Mendoza, L. Dorantes-Álvarez, D. Tellez-Medina, E. M. Jaramillo-Flores, Biochemical and molecular analysis of some commercial samples of chilli peppers from Mexico, J. Biomed. Biotechnol., Article ID 873090, doi: 10.1155/2012/873090, (2012).

[36] M. Rodríguez-Maturino, A. Valenzuela-Solorio, R. Troncoso-Rojas, D. González-Mendoza, O. GrimaldoJuarez, M. Aviles-Marin, L. Cervantes-Diaz, Antioxidant activity and bioactive compounds of Chiltepin (Capsicum annuum var. glabriusculum) and Habanero (Capsicum chinense): A comparative study, J. Med. Plants Res., 6, 1758-1763 (2012).

[37] J. H. Lee, T. H. Sing, K. T. Lee, M. R. Kim, Effect of gamma-irradiation on color, pungency, and volatiles of Korean red pepper powder, J. Food Sci., 69(8), 585-592 (2004).

[38] H. H. Orak, M. Demirci, Effect of different blanching methods and period of frozen storage on enzyme activities and some quality criterias of hot and sweet red pepper (Capsicum annuum L.), Pak. J. Biol. Sci., 8, 641648 (2005).

[39] A. A. H. Gibbs, W. L. O'Garro, Capsaicin content of West Indies hot pepper cultivars using colorimetric and chromatographic techniques, HortScience, 39(1), 132 135 (2004)
[40] G. F. Antonious, T. Berke, R. L. Jarret, Pungency in Capsicum chinense: Variation among countries of origin, $J$. Environ. Sci. Health Part B, 44, 179-184 (2009).

[41] Z. A. A. Othman, Y. B. H. Ahmed, M. A. Habila, A. A. Ghafar, Determination of capsaicin and dihydrocapsaicin in Capsicum fruit samples using high performance liquid chromatography, Molecules, 16, 8919-8929 (2011).

[42] C. O. Nwokem, E. B. Agbaji, J. A. Kagbu, E. J. Ekanem, Determination of capsaicin content and pungency level of five different peppers grown in Nigeria, New York Sci. J. 3, 17-21 (2010).

[43] A. Gahungu, E. Ruganintwali, E. Karangwa, X. Zhang, D. Mukunzi, Volatile compounds and capsaicinoid content of fresh hot peppers (Capsicum Chinense) scotch bonnet variety at red stage, Adv. J. Food Sci. Technol., 3, 211-218 (2011).

[44] P. López, S. Gorzalczany, C. Acevedo, R. Alonso, G. Ferraro, Chemical study and anti-infl ammatory activity of Capsicum chacoense and C. baccatum, Rev. Bras. Farmacogn., 22, 455-458 (2012).

[45] J. Juangsamoot, C. Ruangviriyachai, S. Techawongstien, S. Chanthai, Determination of capsaicin and dihydrocapsaicin in some hot chilli varieties by RP-HPLC-PDA after magnetic stirring extraction and clean up with $\mathrm{C}_{18}$ cartridge, Int. Food Res. J., 19, 1217-1226 (2012).

[46] I. Perucka, M. Materska, Phenylalanine ammonia-lyase and antioxidant activities of lipophilic fraction of fresh pepper fruits Capsicum annuum L., Innov. Food Sci. Emerg. Technol., 2, 189-192 (2001).

[47] W. Kraikruan, S. Sukprakarn, O. Mongkolporn, S. Wasee, Capsaicin and dihydrocapsaicin contents of Thai chili cultivars, Kasetsart J. (Nat. Sci.), 42, 611-616 (2008).

[48] Y. Sung, Y. Chang, N. L. Ting, Capsaicin biosynthesis in water-stressed hot pepper fruits, Bot. Bull. Acad. Sinica, 46, 35-42 (2005).

[49] C. D. Johnson, R. D. Decoteau, Nitrogen and potassium fertility affects Jalapeño pepper plant growth, pod yield, and pungency, HortScience, 31, 1119-1123 (1996).

[50] V. Supalkova, H. Stavelikova, S. Krizkova, V. Adam, A. Horna, L. Havel, P. Ryant, P. Babula, R. Kizek, Study of capsaicin content in various parts of pepper fruit by liquid chromatography with electrochemical detection, Acta Chim. Slov., 54, 55-59 (2007).

[51] A. Canto-Flick, E. Balam-Uc, J. J. Bello-Bello, C. Lecona-Guzmán, D. Solís-Marroquín, S. Avilés-Viñas, E. Gómez-Uc, G. López-Puc, N. Santana-Buzzy, Capsaicinoids content in habanero pepper (Capsicum chinense Jacq.): hottest known cultivars, HortScience, 43, 1344-1349 (2008)

[52] V. S. Govindarajan, Capsicum production, technology, chemistry, and quality. Part IIII: Chemistry of the colour, aroma and pungency stimuli, CRC Crit. Rev. Food Sci. Nutr., 24, 254-355 (1986).

[53] E. A. Weiss, Spice Crops, CABI Publishing International, New York, 2002, pp. 411. 